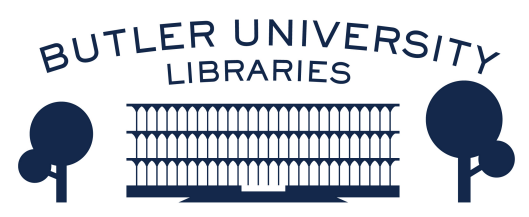

Journal of Hindu-Christian Studies

\title{
Book Review: Dancing Bodies of Devotion: Fluid Gestures in Bharata Natyam
}

\author{
Michelle Voss Roberts \\ Wake Forest University School of Divinity
}

Follow this and additional works at: https://digitalcommons.butler.edu/jhcs

Part of the Christianity Commons, Hindu Studies Commons, and the Religious Thought, Theology and Philosophy of Religion Commons

\section{Recommended Citation}

Roberts, Michelle Voss (2017) "Book Review: Dancing Bodies of Devotion: Fluid Gestures in Bharata Natyam," Journal of Hindu-Christian Studies: Vol. 30, Article 25.

Available at: https://doi.org/10.7825/2164-6279.1677

The Journal of Hindu-Christian Studies is a publication of the Society for Hindu-Christian Studies. The digital version is made available by Digital Commons @ Butler University. For questions about the Journal or the Society, please contact cbauman@butler.edu. For more information about Digital Commons @ Butler University, please contact digitalscholarship@butler.edu. 
for the faint-hearted. That he would open the Eucharist to all, all the time, seems highly doubtful.

In "On Doing What Others Do: Intentions and Intuitions in Multiple Religious Practice" S. Mark Heim offers a typically subtle reflection that is both substantively theological and intimately personal, on the theological and personal dimensions of participation, including accounts of his own visits to temples in India and the United States. Interestingly, because he recognizes the close parallel of Vaisnavism to Christianity, he is therefore less comfortable in participating in Vaisnava worship since "particular devotion to a Hindu deity would intrude on space that I devote to Christ," and perhaps re-define him as a Hindu. (30) So Heim too prefers an Advaita terminology that sees the deities as symbols of a greater reality beyond them. It would be interesting then to explore further how the Christian-Vaisnava phenomenon offers a deep resonance and sacramental resonance that creates different possibilities and difficulties than considered here.

In his succinct summation at volume's end Joris Geldhof notes that complexity is still the order of the day, perhaps all the more so after these essays have done their work. When we become aware of the complexities of participation, the multiple individual and communal perspectives on every manner of encounter, and accordingly the daunting challenge to theologians to make sense of all this, the list of possibilities, questions, and concerns will only grow. But for now, this timely and valuable volume helps us to move forward in addressing a key phenomenon of this century.

Francis X. Clooney

Harvard University

\section{Dancing Bodies of Devotion: Fluid Gestures in Bharata Natyam. By Katherine C. Zubko. Lanham, MD: Lexington Books, 2014, xvii + 251 pages.}

NOT only does Dancing Bodies of Devotion deal with performative art-bharata natyam, an Indian dance form-but it is also a tour de force in itself. In this theoretically and methodologically sophisticated presentation, Zubko contributes a genuinely novel composition to the study of Indian religions, performance studies, aesthetics, and interreligious engagement.

Perhaps the most distinctive feature of this work is what Zubko brings to it: her preparation as a dancer, which she puts to work learning bharata natyam herself. Her training positions her to interview dancers and choreographers and to analyze their performances with an extraordinary level of detail. (An illustrated glossary of gestures accompanies the text.) More significantly, training in bharata natyam enables her to understand and theorize her subject matter through a method she calls "embodied ethnography." The embodied process of learning unfamiliar gestures immerses her in the cultural and religious dimensions of the art form in a unique way. This method lends itself to an engaging writing style, in which narrations of the author's experiences and of particular dance pieces draw the reader 
in to the technical, theoretical, and religious dimensions of her argument.

The thrust of the argument is that rasa, the aesthetic mood evoked through dance-drama, has been developed through bharata natyam to manifest a devotional mood that crosses religious boundaries. Vivid examples from Hindu, Christian, Buddhist, Muslim, and interreligious themes in the choreography of bharata natyam pieces demonstrate, first, how bhakti rasa has become a pan-Indian sensibility; and, second, how the dance form, which has sometimes been defined in religiously Hindu terms, moves across religious lines.

The book's structure guides the reader through four movements, each of which progresses from an engaging personal narrative to traditional aesthetic theory, to ethnographic data, and finally to conclusions that engage and advance contemporary scholarship. The movements build upon one another effectively, so that the later parts of the book are only possible because of the earlier ones.

Part I, "Religious Bodies," explores the personal religious import of bharata natyam to the dancers, who often frame their experience in terms of bhakti rasa, the devotional mood. After a chapter explaining how bhakti became a rasa, Zubko shows through two performative contexts how this development has transformed rasa itself. If the earlier texts theorized rasa as a taste of a generalized (or universal) emotion through aesthetic experience, the dancers have "repersonalized" rasa so that their art expresses their own longing for the divine and puts them in contact with the deity. As a result, the audience's experience of bhakti rasa is also personalized so that watching a performance of a religious narrative is akin to darshan.
Part II, "Cultural Bodies," takes the generalized or universal dimension of rasa (sadharanya) in a different direction, showing how it allows bhakti rasa-and bharata natyamto cross religious lines. As pan-Indian categories, both bhakti and rasa provide shared cultural referents that dancers from various religious communities can use with creative variation. Zubko draws on A. K. Ramanujan's argument about the relation of contextsensitive and context-free dimensions of "Indianness." Bhakti rasa, as idealized and therefore context-free, can float free of Hindu identity and become coded with the particular markers of other religious traditions.

Indian aesthetic theory assigns an educative function to dance and drama: they teach viewers how to live. According to traditional authorities, audiences can best receive these dharmic lessons if the performance follows the principle of appropriateness (aucityam). In Part III, "Ethical Bodies," Zubko illustrates how contemporary dancers employ bhakti rasa to convey moral messages. Dancing is part of the dancer's dharma, a kind of puja to the deity, which entails a duty to create a devotional or moral mood for others to enjoy. Leela Prasad's "poetics of conduct" serves as a framework for understanding how ethical bodies are created through multiple sources, including embodied performance and aesthetic experience.

Having demonstrated how bharata natyam and bhakti rasa both cross religious lines, Zubko turns in Part IV, "Pluralistic Bodies," to choreography that purposefully takes up the theme of religious pluralism. Dance can create and evoke dialogue. Zubko's case studies, along with the theme of the oneness of rasa among its various moods, enable her to analyze the often clichéd term "unity-in-diversity." Beyond 
appeals to secularism or the Rg Vega's aphorism proclaiming the oneness and many names for truth, contemporary dancers have also creatively evoked bhakti rasa as a human connection that expands its devotional, cultural, and ethical meanings into an imperative for cooperation and dialogue.

Throughout this text, Zubko demonstrates her mastery of texts, theory, and technical detail. Her overviews of the construction of both rasa and bharata natyam are exemplary. Only in the conclusion of the fourth movement did I find myself hoping for more. Unlike each of the first three sections, which close their argument by engaging relevant theory, the fourth misses an opportunity to connect with contemporary conversations on religious pluralism and dialogue. The conclusion helpfully addresses how exclusivity can be embedded in tolerance; and it nicely ties this theme back to the question of which types of identity are permitted in bharata natyam. Because themes of exclusion, inclusion, pluralism, and identity are central to theologies of religion, this reader is curious about how the cases discussed here could amplify those conversations.

Michelle Voss Roberts

Wake Forest University School of Divinity

\section{The Continuing Quest: Carrying Forward the Contemplative and Prophetic Vision of Bede Griffiths. Edited by Thomas Matus and Joseph Wong. Editions of Sankt Ottilien, Germany, 2016, 304 pages.}

THIS volume is a study of the theologian Bede Griffiths (1906-1993), a monk who went to India and immersed himself in the Hindu tradition of spirituality and created his own experiencecentered version of Advaita Vedanta. It originated in a 2006 conference of the Camaldolese Institute for East-West dialogue at Big Sur, California. Griffiths was one of the first Christian monastics to explore Hinduism in depth. It features articles by specialists on Hinduism and on Christian monastic spirituality, a number of whom would consider themselves to be followers of the contemplative spiritual path.

At the start of the book, there is a good overview of the volume which has been provided by the two editors and which gives some good context. The first article by comparative theologian Francis Clooney is a critical analysis of Vedanta and Christian Faith, one of Griffiths' major works. Clooney criticizes Griffiths, not for his spiritual path, but for his version of Advaita Vedanta which Clooney, no doubt rightly, considers weak in its attention to the technical commentaries on Advaita and their specific questions and vocabulary. The commentarial tradition is an area in which Clooney has worked extensively. He argues that the thought of a figure like Sankara can only be recovered in this way, since Sankara says almost nothing about his own spiritual experiences.

Brad Malkovsky's article stresses the significant differences in the theology of revelation between Hinduism and Christianity. In particular, the Christian understanding of divine revelation as something which 